\title{
TEMATSKE DODATNE OZNAKE KAO DIO PREDMETNOGA SUSTAVA KNJIŽNICA GRADA ZAGREBA
}

\author{
TOPICAL SUBDIVISIONS AS PART \\ OF THE LIBRARY SUBJECT SYSTEM \\ OF THE ZAGREB CITY LIBRARIES
}

Silvija Zec

Knjižnice grada Zagreba

silvija.zec@kgz.hr

UDK / UDC: 025.4:025.343(497.5 Zagreb)

Stručni rad / Professional paper

Primljeno / Received: 22. 1. 2021.

Prihvaćeno / Accepted: 20. 8. 2021.

\section{Sažetak}

Cilj. U tekstu se analiziraju predmetne odrednice koje čine pomoćni rječnik predmetnoga jezika koji se prema Pravilniku za predmetni katalog Knjižnica grada Zagreba naziva tematskim dodatnim oznakama. Kroz terminološku analizu i praktične primjere predmetnoga označivanja ukazuje se na iskustva odabira i korištenja te vrste predmetnih odrednica. Pokazuju se osobitosti predmetnoga označivanja u sustavu Knjižnica grada Zagreba.

Pristup/metodologija/dizajn. Daje se prikaz teorijske osnove za pristup toj vrsti predmetnih odrednica. Tematske dodatne oznake analiziraju se terminološki kako bi se ukazalo na jezične aspekte njihova odabira i korištenja. Opisuju se i problemi koji su se pojavili u rječniku zbog nedovoljnoga normativnog nadzora.

Rezultati. Na primjerima iz prakse predmetnoga označivanja rad pokazuje kako se pomoću tematskih dodatnih odrednica nastoji postići točnost i iscrpnost u označivanju različitih tema prisutnih prvenstveno u građi s područja društvenih i humanističkih znanosti te pridonijeti boljoj pretraživosti te građe s gledišta korisnika. Ističe se važnost

Vjesnik bibliotekara Hrvatske 64, 2(2021), 361-382

ISSN 0507-1925 
odabira riječi kojima se u pomoćnom rječniku dodatno označuju različiti predmeti, kao i važnost sustavnoga nadzora nad svim dijelovima rječnika predmetnoga jezika.

Originalnost/vrijednost. Analiziraju se predmetne odrednice koje čine pomoćni rječnik predmetnoga jezika, a koje su rijetko predmetom analize.

Ključne riječi: odabir rječnika, predmetni sustav Knjižnica grada Zagreba, predmetno označivanje, tematske dodatne oznake

\begin{abstract}
Purpose. The article analyses topical subdivisions that make up the auxiliary vocabulary of the subject language of the Zagreb City Libraries, called additional thematic subject headings. Through a terminological analysis and practical examples of subject headings designation, the experiences of selecting and using this type of subject headings are pointed out. Some specific characteristics of subject indexing in the Zagreb City Libraries system are shown.
\end{abstract}

Approach/methodology/design. A theoretically based approach to topical subdivisions is presented. The terminology of the additional thematic subject headings is analysed to point out linguistic aspects of their choice and usage. The problems that occur due to insufficient managing and supervision of the controlled vocabulary are also described.

Findings. Based on practical experience and examples the paper presents how the topical subdivisions are used to achieve precision and exhaustiveness by indexing different subjects mostly in library materials from the field of social sciences and humanities. This process should also contribute to a better retrieval effectiveness of these documents from different users' viewpoints. The importance of selecting additional terms by which different subjects are more specifically indexed is established as well as the importance of the systematic supervision of all parts of the subject headings controlled vocabulary.

Originality/value. The paper analyses the rarely discussed additional thematic subject headings that make up the auxiliary vocabulary of the main controlled vocabulary in the Zagreb City Libraries library system.

Key words: subject indexing, subject system of the Zagreb City Libraries, topical subdivisions, vocabulary selection 


\section{Uvod}

U svrhu predmetnoga označivanja i pretraživanja knjižnične građe predmetni se jezici služe specifično oblikovanim rječnicima i za njih prilagođenom semantikom i sintaksom. Uz popise odrednica koje čine glavni rječnik, svaki predmetni jezik izgrađuje i svojevrsni „pomoćni“ rječnik. U ovome se tekstu analiziraju osobitosti pomoćnoga rječnika predmetnih odrednica koje se u predmetnom jeziku Knjižnica grada Zagreba (dalje u tekstu KGZ) prema Pravilniku za predmetni katalog $^{1}$ nazivaju tematskim dodatnim oznakama. ${ }^{2}$

Teorijski model FRSAD, ${ }^{3}$ koji je u konačnoj verziji 2011. godine objavila IFLA-ina Radna skupina za Uvjete za funkcionalnost predmetnih preglednih zapisa, donosi (najširi) konceptualni pristup nadziranim rječnicima predmetnih odrednica. Kako bi se razumjeli uvjeti koji će osigurati učinkovitost autoriziranih predmetnih odrednica, model FRSAD uvodi dva nova entiteta koji se pridodaju postojećim entitetima identificiranima u drugim konceptualnim modelima za bibliografske opise. Ti su entiteti thema i nomen. Thema je bilo koji entitet upotrijebljen kao predmet djela. Nomen je bilo koji znak - alfanumerički, simbol, zvuk itd. - ili niz takvih znakova po kojima je thema poznata i po kojima se na nju upućuje ili se ona njima iskazuje/izriče. ${ }^{4}$

Između theme i nomena uspostavlja se odnos: thema ima naziv, to jest nomen, i nomen je naziv theme. ${ }^{5} \mathrm{~S}$ gledišta nadziranoga rječnika predmetnih odrednica može se reći da su nomeni nazivi za vodeće predmetne odrednice kojima su označene različite theme prisutne u knjižničnoj građi.

Američka knjižničarka Elaine Svenonius, u svome glavnom teorijskom djelu Intelektualne osnove organizacije informacija,${ }^{6}$ donosi razliku između dvaju dijelova nadziranoga rječnika predmetnoga jezika. Prvi je dio takozvani „tehnički rječnik“ ili rječnik naziva. Nazivi su definirani kao riječi i kombinacije riječi (složeni nazivi) posebne namjene koji se upotrebljavaju za imenovanje glavnih pojmova. Unutar određenoga znanstvenog područja nazivi su kontekstualno neovisni tako da mogu stajati samostalno kao označitelji sadržaja predmeta. ${ }^{7}$ Nazivi koji prema E. Svenonius čine tehnički rječnik istovjetni su nomenima prema FRSAD-ovom modelu. S gledišta oblikovanja predmetnoga jezika i prakse predmet-

\footnotetext{
Štrbac, D.; M. Vujić. Pravilnik za predmetni katalog. Zagreb: Knjižnice grada Zagreba, 2004.

Usp. isto, str. 104. i str. 119.

3 Uvjeti za funkcionalnost predmetnih autoriziranih podataka: Konceptualni model. / urednice

M. Lei Zeng, M. Žumer i A. Salaba. Zagreb: Hrvatsko knjižničarsko društvo, 2012.

4 Usp. isto, str. 17-20.

5 Usp. isto, str. 26.

6 Svenonius, E. Intelektualne osnove organizacije informacija. Lokve: Benja, 2005.

7 Isto, str. 127.
} 
noga označivanja radi se dakle o vodećim odrednicama koje nastaju korištenjem glavnih kategorija predmetnih odrednica.

Vodeće predmetne odrednice i od njih stvoreni nazivi (nomeni), kao i njihovo korištenje u složenim predmetnim odrednicama, ne omogućuju uvijek da se na dostatan način označi neki sadržaj prisutan u dokumentu. Stoga predmetni jezici nužno razvijaju i svoje pomoćne ili, prema Elaine Svenonius, „ne-tehničke rječnike“. ${ }^{8}$ Taj pomoćni rječnik čine „tematske dodatne oznake“, kako se nazivaju u predmetnom sustavu KGZ-a, ili „višenamjenske dodatne odrednice“, naziv koji nalazimo u Pravilniku i priručniku za predmetne odrednice Nacionalne i sveučilišne knjižnice u Zagrebu (NSK). ${ }^{9}$ Zajedničko obilježje tih predmetnih odrednica u obama predmetnim sustavima jest to da su one prvenstveno određene time što su opći pojmovi i što se koriste isključivo kao dodatne odrednice. Pravilnik za predmetni katalog KGZ-a definira ih u tome smislu kao opće pojmove koji se po svojoj funkciji u složenoj predmetnoj odrednici razlikuju od općih pojmova koji su vodeće oznake. ${ }^{10}$ Odnosno, tematske dodatne oznake u predmetnom se sustavu KGZ-a, kao i višenamjenske dodatne odrednice u predmetnom sustavu NSK-a, nikada ne javljaju na prvom mjestu u složenim predmetnim odrednicama. ${ }^{11}$

Tematske dodatne oznake kao isključivo dodatne odrednice ovise o odrednicama koje im prethode. Razlozi za to proizlaze iz činjenice da one same nemaju dovoljno „samodostatnoga“ značenja ili sadržaja da bi samostalno činile naziv (npr. različita gledišta - sociološko gledište, kršćansko gledište, ili neka svojstva - brojivost, stabilnost, ili procesi - istraživanje, razvoj), ili su pak u slučajevima kada je njihov sadržaj „bogatiji“, određeniji (npr. anomalije, zastara) i dalje kontekstualno ovisne o predmetnim oznakama ili nazivima koji im prethode i uz koje se semantički vežu. Zbog toga E. Svenonius, govoreći o ne-tehničkom rječniku, kaže da bi se on mogao nazvati „nenazivni“" rječnik. ${ }^{12}$

8 Isto, str. 135-136.

9 Pravilnik i priručnik za predmetne odrednice. Zagreb: Nacionalna i sveučilišna knjižnica, 2019. Str. 126-127; 319. [citirano 2020-10-27] Dostupno na: http://ps.nsk.hr/wp-content/uploads/2019/09/Pravilnik-i-priru\%C4\%8Dnik-za-predmetne-odrednice-srpanj-2019-v2.pdf.

10 Štrbac, D.; M. Vujić. Nav. dj., str. 119.

${ }^{11}$ Za razliku od Pravilnika za predmetni katalog KGZ-a koji je dao samo definiciju tematskih dodatnih oznaka, Pravilnik i priručnik za predmetne odrednice NSK-a, uz definiciju višenamjenskih dodatnih odrednica i njihovo razlikovanje od ostalih vrsta dodatnih odrednica, propisuje i način na koji se one koriste iza pojedinih vodećih odrednica. U njemu se razlikuje pet vrsta višenamjenskih dodatnih odrednica: formalne i tematske dodatne odrednice opće primjene, dodatne odrednice za korištenje uz klase osoba i etničke grupe, dodatne odrednice za korištenje uz imena pojedinačnih korporativnih tijela, osoba i obitelji, dodatne odrednice za korištenje uz geografska imena i dodatne odrednice kontrolirane oglednim odrednicama. Također se navodi i iscrpan popis odrednica za svaku od navedenih vrsta. Vidi: Pravilnik i priručnik za predmetne odrednice. Nav. dj., str. 126-316.

12 Usp. Svenonius, E. Nav. dj., str. 136. Ovdje se svakako mora napomenuti da autorica Svenonius u izvorniku koristi izraz nonterms, a u hrvatskom prijevodu (M. Willer) to je prevedeno kao nenazivi. 
Ta ovisnost o kontekstu ne čini tematske dodatne odrednice manje važnima. Štoviše, u ne-tehnički rječnik uvode se odabrane riječi i sintagme kako bi se dodatno označila različita svojstva, stanja, radnje, procesi i/ili okolnosti neke teme koji nisu mogli biti označeni vodećim odrednicama (nazivima) povezanima s drugim vrstama dodatnih odrednica (vremenskim, geografskim i/ili odrednicama za oblik).

Tematske dodatne oznake kao manji dio ukupnoga rječnika predmetnoga jezika nose obilježja predmetnoga sustava KGZ-a u cjelini. Njihove osobitosti treba razmatrati, s jedne strane, u vezi s namjenom knjižnica, odnosno strukturom fondova i vrstom korisnika na čije se informacijske potrebe nastoji odgovoriti. Te okolnosti utječu na indeksnu politiku sadržajne obrade, odnosno na sadržaj i veličinu domene rječnika. S druge strane, analiza tematskih dodatnih oznaka vezana je uz činjenicu da se predmetni jezik KGZ-a oblikuje na temelju Pravilnika za predmetni katalog ${ }^{13}$ (dalje u tekstu Pravilnik), o kojemu će također biti riječi.

Analiza tematskih dodatnih oznaka nudi priliku da se ukaže i na neke kulturološke i jezične izazove izgradnje predmetnoga jezika s kojima se susreću knjižničari kada nastoje međunarodno prihvaćena načela za predmetnu obradu primijeniti u izgradnji određenoga predmetnog jezika. Izazovi proizlaze iz same prirode predmetnoga jezika, odnosno iz činjenice da je za taj umjetni jezik, za razliku od drugih bibliografskih jezika, presudna vezanost uz riječi prirodnoga jezika iz kojega nastaje i izgrađuje vlastiti rječnik, semantiku i sintaksu. Odnosno, prema tumačenju E. Svenonius, predmetni jezik odabire iz prirodnoga jezika manji broj riječi i fraza, ${ }^{14}$ a zatim im određuje značenje i odnose s drugim nazivima, nastojeći ih ,izbrusiti“" kako bi postali što točniji. Nastali rječnik uređen je tako da se svaki pojedini naziv odnosi samo na jedan pojam ili predmet, a svaki je predmet ili pojam označen samo jednim nazivom. ${ }^{15}$ Ostvarivanje bibliografskih ciljeva pomoću predmetnoga jezika nije uvijek jednostavno upravo iz jezičnih razloga. Predmetnim odrednicama treba označiti različite predmete za koje se pretpostavlja da će biti važni korisnicima, i to treba učiniti uz odgovarajući odabir riječi koje će osigurati pristup tim sadržajima.

Na primjeru „tematskih dodatnih oznaka“ nastojat ćemo pokazati kako se ti izazovi izgradnje predmetnoga jezika rješavaju kroz dva temeljna aspekta bilo kojega nazivlja, pa onda i nazivlja određenoga predmetnog jezika, to jest kroz aspekte pojmova/sadržaja koje ti nazivi označuju i aspekte jezika/jezičnih izraza kojima su ti pojmovi označeni.

Prije toga, potrebno je ukazati na osobitosti predmetnoga jezika KGZ-a u cjelini, iz kojega proizlazi specifičan način oblikovanja tih predmetnih oznaka.

\footnotetext{
13 Štrbac, D.; M. Vujić. Nav. dj., str. 119-124.

14 Usp. Svenonius, E. Nav. dj., str. 130.

15 Usp. isto, str. 126-127.
} 


\section{Osobitosti predmetnoga jezika KGZ-a}

Na razvoj i osobitosti predmetnoga jezika KGZ-a od 2000. godine nadalje utjecalo je nekoliko okolnosti. Prvo, taj se jezik razvijao kroz obradu građe koju u fondovima imaju knjižnice u mreži KGZ-a. Mrežu čine uglavnom narodne knjižnice ${ }^{16}$ kojima je zadatak odgovoriti na očekivane potrebe svojih korisnika. Stoga su struktura fondova, kao i pretpostavljeni opseg informacijskih potreba korisnika, utjecali na osobitosti toga dokumentacijskog jezika. S obzirom na to da u ukupnom fondu KGZ-a postoji nešto veća zastupljenost građe s područja društveno-humanističkih u odnosu na prirodne i tehničke znanosti, u rječniku predmetnoga jezika prisutna je veća zastupljenost naziva iz tih znanstvenih područja.

Potrebno je to imati u vidu jer je normiranje nazivlja u tim znanstvenim područjima posebno osjetljivo zbog teže jednoznačne leksičke određenosti naziva/ predmeta o kojima je u njima riječ. Za razliku od prirodnih znanosti koje upotrebljavaju stabilniji i veći tehnički rječnik, kako upozorava E. Svenonius, u području društvenih i humanističkih znanosti rječnik je ,nestabilniji“ i sadrži nazive kojima sadržaji nerijetko bivaju, ovisno o autoru, različito definirani. Tako na primjer pojam kulture može imati toliko pridruženih značenja koliko ima znanstvenika koji o njemu pišu, ${ }^{17}$ a česta je upotreba sinonima.

Na semantičke aspekte nazivlja utječu i kulturološke veze između predmetnoga i prirodnoga jezika. Područja društvenih i humanističkih znanosti, kako je to slikovito istakla Maria Inês Cordeiro, znanstvena su područja u kojima su različiti jezici sami za sebe skladišta specifičnoga znanja i informacija koja pripadaju nekoj lokalnoj ili regionalnoj kulturi, ${ }^{18}$ te gdje se kroz usvojeno nazivlje prenose različita kulturno-povijesna iskustva. Tako je u rječnicima pojedinih predmetnih sustava moguće pronaći nazive koje drugi predmetni jezici, stvarani u sredinama s drugačijim kulturno-povijesnim iskustvima, ne poznaju ili ih ne koriste. ${ }^{19}$ Također je moguće da se u različitim predmetnim jezicima koriste isti nazivi, ali u različitim značenjima, ili da se prednost daje korištenju različitih naziva kada se želi iskazati isti predmet, ili da u višerječnim nazivima, kao i složenim predmetnim odrednicama problem predstavlja sintaksa.

\footnotetext{
16 KGZ je mreža narodnih knjižnica, u kojoj su Gradska knjižnica i Knjižnica Božidara Adžije, po svojim zbirkama i zadaćama narodne i znanstvene knjižnice.

17 Svenonius, E. Nav. dj., str. 135.

18 Cordeiro, M. I. Organizacija znanja i predmetne odrednice: Jačanje jedne od najslabijih točaka međunarodnog knjižničarstva. // Vjesnik bibliotekara Hrvatske 44, 1/4(2001), str. 135.

19 Na primjer, naziv „pretvorba društvenog vlasništva“, kojim je označena jedna od važnih pojava u gospodarskoj i društvenoj tranziciji devedesetih godina dvadesetoga stoljeća u Hrvatskoj i još nekim socijalističkim zemljama u tranziciji, ne koristi se u anglo-američkim i drugim predmetnim jezicima, koji će tu pojavu najbliže opisati nazivom ,privatizacija“, što nije isto.
} 
Rječnik predmetnoga jezika KGZ-a razvijao se ab ovo, tj. od prvoga u računalo unesenoga naziva nadalje, ne preuzimajući unaprijed stvoreno nazivlje. Nazivlje se stvaralo prema „načelu predloška“, na temelju knjižnične građe i naziva koje koriste hrvatski autori u domaćim stručnim, znanstvenim, umjetničkim i popularno-znanstvenim djelima, kao i naziva prisutnih u djelima stranih autora. Pri izgradnji nazivlja velika se pozornost pridavala i „načelu korisnika“ ${ }^{20} \mathrm{U}$ rječnik su kao pristupnice odabirane one riječi za koje se smatralo da će odgovarati načinu na koji će korisnici (samostalno) riječima prirodnoga jezika oblikovati upite u katalogu. Također, označeni su oni specifični aspekti predmeta za koje se smatralo da bi mogli odgovarati njihovim informacijskim potrebama.

Sljedeća je važna okolnost oblikovanja predmetnoga jezika KGZ-a pitanje pravila koja upravljaju njegovom izgradnjom, to jest načina na koji se u Pravilni$k u$ osigurava izvedba međunarodnih načela, smjernica i standarda za oblikovanje predmetnoga jezika i provedbu sadržajne analize dokumenata. Što se tiče općih načela oblikovanja, Pravilnik je donio definicije glavnih kategorija predmetnih oznaka/odrednica i propisao prvenstveno logičke (semantičke) odnose među njima, ne propisujući na dostatan način sintaksu i način oblikovanja pojedinih vrsta odrednica. Normativni nadzor naročito je izostao u slučaju tematskih dodatnih oznaka o kojima je u ovom radu riječ.

Na razini izvedbe Pravilnik je istaknuo točnost $\mathrm{i}$ iscrpnost $\mathrm{u}$ iskazivanju predmeta kao glavno obilježje indeksne politike i detaljno ju opisao kroz petnaest „Općih načela dodjeljivanja predmetnih odrednica“". ${ }^{21}$ Zahtjev za točnim označivanjem predmeta iskazan je kroz načelo koje kaže da odrednica mora svojim opsegom odgovarati sadržaju na koji se odnosi, tj. ne smije biti ni šira ni uža od sadržaja dokumenta. ${ }^{22}$ Iscrpnost je vidljiva u dubini do koje se predmetno analiziraju dokumenti (predmetno se obrađuje cjelina koja broji dvadesetak stranica teksta zastupljenoga u cijelom dokumentu, iznimno i manje), u neograničavanju ukupnoga broja predmetnih odrednica koje se mogu dodijeliti nekomu dokumentu, kao i u dubini do koje se analizira svaki pojedini sadržaj/predmet/tema i izražava uz pomoć dodatnih odrednica u složenim predmetnim odrednicama. Primjenom tih načela stvoreni su brojni nizovi predmetnih odrednica, u kojima se predmet opisuje s različitih aspekata, u rječničku su domenu uvedeni nazivi koji semantički upotpunjavaju strukturu jezika, a građa je detaljno predmetno obrađena. Naglasak

20 Prema načelu korisnika odabir rječnika za predmetno označivanje treba biti primjeren načinu na koji se korisnici određene vrste knjižnica, općega ili specijalnoga tipa, služe jezikom oblikujući svoje upite. Usp. Principles unederlaying subject heading languages (SHLs). / ed. by I. Lopes and J. Beall; Working Group on Principles Underlying Subject Heading Languages; Approved by the Standing Committee of the IFLA Section on Classification and Indexing. München: K. G. Saur, 1999. Str. 2.

${ }^{21}$ Usp. Štrbac, D.; M. Vujić. Nav. dj., str. 17-18.

22 Usp. isto, str. 17. 
na iscrpnosti u označivanju predmeta, uz već spomenutu potrebu da se rječnik što više prilagodi pretpostavljanim potrebama korisnika narodnih knjižnica i jezično približi njihovim upitima, značajna su obilježja toga predmetnog jezika i njegova rječnika, vidljiva i u slučaju tematskih dodatnih oznaka.

Međutim, nedovoljan normativni nadzor nad rječnikom koji je brzo rastao, imao je za posljedicu potrebu za naknadnim normiranjem, odnosno popravcima u rječniku i sintaksi. Određene promjene u tome smislu već su usvojene kroz interne dopune i korekcije Pravilnika i provode se u praksi predmetnoga označivanja. U rječniku je kao posljedica opisanih okolnosti učestala pojava zalihosti (redundancije), to jest suviška predmetnih odrednica, koji je nerijetko nastao upravo zbog nedovoljno kontroliranoga korištenja tematskih dodatnih oznaka. Zbog toga se početkom 2020. godine započelo s revizijom ne-tehničkoga rječnika, prilikom koje se provelo normiranje i pročišćavanje rječnika od suvišnih tematskih dodatnih oznaka. Stvoreni višak predmetnih odrednica omogućuje da se između brojnih odrednica prilikom revizije odaberu one koje će, s gledišta izgradnje kontroliranoga rječnika predmetnoga jezika, kao i s gledišta korisnika, biti bibliografski važne, što bi bio svojevrstan pozitivan učinak tih okolnosti.

\section{Tematske dodatne oznake u rječniku predmetnoga jezika KGZ-a}

U normativnoj računalnoj bazi KGZ-a, koja obuhvaća sve normirane zapise za imena i sve predmetne odrednice, samo za potrebe predmetnoga sustava KGZ-a od 2000. godine do početka 2021. godine napravljena je ukupno 118661 predmetna odrednica. Od toga je broja ukupno 11493 općih pojmova koji su normirani pregledni predmetni zapisi. Istovremeno, u pomoćnom rječniku nalaze se 1904 tematske dodatne oznake, koje trenutno čine $14 \%$ svih općih pojmova u normativnoj bazi. ${ }^{23}$

Odabir i uvrštavanje predmetnih odrednica u rječnik predmetnoga jezika obilježeno je izborom određenoga manjeg broja vrsta riječi prirodnoga jezika, koje se zatim normiraju kako bi se odredili njihovi semantički odnosi i sintaksa.

Sve usvojene vodeće odrednice u rječniku, odnosno sve nazive za nomene, kao $\mathrm{i}$,nenazive“" u pomoćnom rječniku, slično kao i deskriptore u tezaurusima, ${ }^{24}$ moguće je analizirati na način obrazložen u Hrvatskome terminološkom priručniku. ${ }^{25}$ Svaki naziv ima dvije strane. On je pojam, to jest ima neki sadržaj i značenje, koje

\footnotetext{
23 Podatci su navedeni prema statistici na dan 21. 1. 2021. godine. Nakon revizije ovoga dijela rječnika koja je u tijeku, očekuje se da će se broj tematskih dodatnih oznaka smanjiti.

24 Urbanija, J. Metodologija izrade tezaurusa. Zagreb, 2005. Str. 18-19.

25 Hudaček, L.; M. Mihaljević. Hrvatski terminološki priručnik. 3. ispravljeno izd. Zagreb: Hrvatski institut za jezik i jezikoslovlje, 2012.
} 
u slučaju predmetnoga jezika treba tumačiti / normirati / jednoznačno odrediti. Pojam je ono što se označuje - „označenik“. S druge strane, naziv ima i svoj jezični izraz, to jest on je riječ (jednorječna riječ) ili skupina riječi (višerječni izraz ili višerječna riječ) kojima je taj pojam označen, on je i „označitelj““. ${ }^{26}$

U glavnome (tehničkom) rječniku predmetnoga jezika KGZ-a za stvaranje jednorječnih naziva koriste se imenice, glagolske imenice i pridjevi. Za oblikovanje višerječnih naziva većinom su u upotrebi imenske sintagme, ${ }^{27}$ zatim višerječni nazivi nastali povezivanjem dvaju zasebnih naziva veznikom ,i“ (npr. djeca i roditelji) ili se nazivi stvaraju od više riječi uz korištenje različitih ortografskih znakova: kvalifikatora kod homonima (npr. Hvar <otok>, Hvar < grad $>$ ), crtice za nazive koji nastaju kombinacijom vodeće i dodatne odrednice (npr. turizam - oglašavanje, Hrvatska - kulturna politika), okruglih zagrada kod imena osoba s dodatkom za autorstvo, npr. Mann Thomas, 1875.-1955. (Smrt u Veneciji), ili Molière, 1622.-1673. (komedije). ${ }^{28}$

U slučaju tematskih dodatnih oznaka izbor vrsta riječi još je dodatno sužen. Za oblikovanje jednorječnih tematskih dodatnih oznaka koriste se imenice i glagolske imenice, a za tematske dodatne oznake koje imaju više od jedne riječi najčešće su u upotrebi imenske sintagme.

Uzimajući u obzir sve navedeno, u predmetnom jeziku KGZ-a možemo razlikovati četiri skupine tematskih dodatnih oznaka. Primjeri složenih predmetnih odrednica koji slijede uz svaku od tih skupina ilustriraju kako pomoću navedenih odrednica kao označitelja dodatno preciznije određuju i posreduju značenja koja vodećim odrednicama nisu bila dostatno obuhvaćena. Uz odabrane primjere složenih odrednica navedeni su i podatci s mrežnoga kataloga KGZ-a (slika 1), koji govore o ukupnom broju jedinica građe uz koje je vezana pojedina tematska dodatna oznaka.

\footnotetext{
26 Usp. isto, str. 13.

27 Pojam sintagma ili sveza koristi se prema definiciji danoj u Hrvatskom pravopisu i Hrvatskoj enciklopediji, to jest kao ,slijed dviju ili više riječi koje čine sintaktičku i semantičku cjelinu“. Usp. Hrvatski pravopis. [citirano: 2021-04-21]. Dostupno na: https://pravopis.hr/pojmovnik/?\&l=s. i Hrvatska enciklopedija. [citirano: 2021-04-21]. Dostupno na: https://enciklopedija. hr/Natuknica.aspx?ID=56163. U nazivlju predmetnoga jezika KGZ-a najčešće su korištene sintagme koje nastaju od imenice i njezina atributa (npr. hrvatsko iseljeništvo), zatim one koje tvore imenica s imenicom u genitivu (npr. dizajn obuće) te imenica povezana s drugom imenicom nekim prijedlogom (npr. sredstva za čišćenje).

28 U rječniku se još koristi i ortografski znak dvotočke za odnos između dvaju predmeta. Vidi: Juraga, M. Specifičnost u oblikovanju predmetnih odrednica za izražavanje odnosa ili utjecaja u predmetnom sustavu Knjižnica grada Zagreba. // Vjesnik bibliotekara Hrvatske 57, 1/3(2014), str. 105-116. [citirano: 2020-11-05]. Dostupno na: https://www.hkdrustvo.hr/vjesnik-bibliotekara-hrvatske/index.php/vbh/article/view/114.
} 


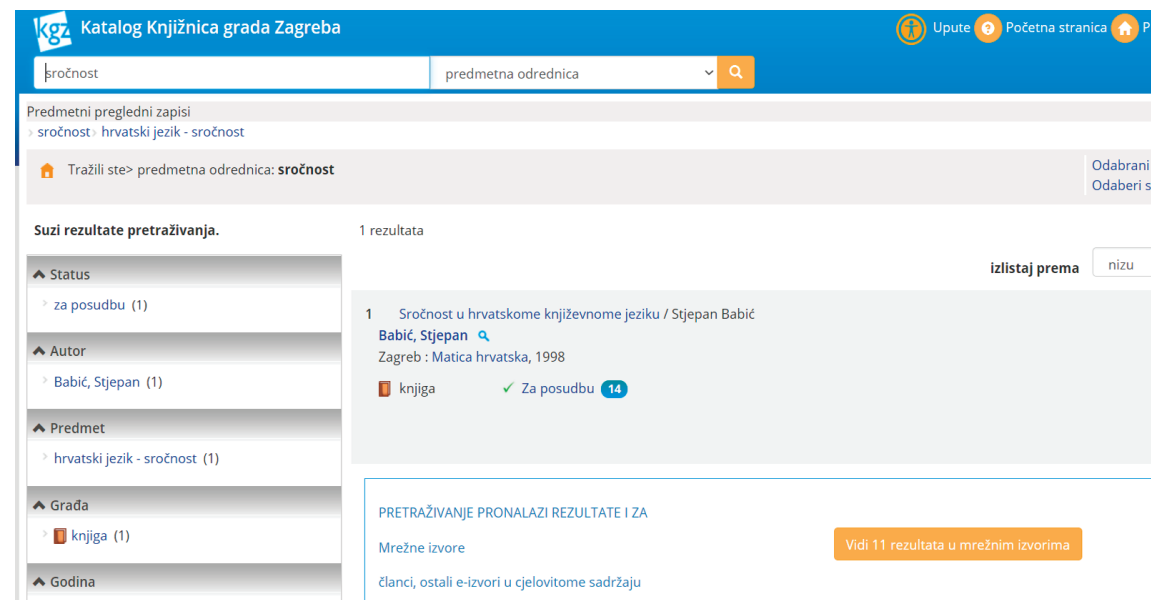

Slika 1. Pretraživanje predmetne odrednice „sročnost“" na mrežnom katalogu KGZ-a ${ }^{29}$

Uz odaziv knjižnične građe, katalog daje i podatke o odazivu građe na mrežnim izvorima, tj. u znanstvenim i stručnim člancima na koje je vezan preko Hrčka - portala otvorenoga pristupa. ${ }^{30}$ Budući da se radi o dodatnim odrednicama i da za većinu ključnih riječi u sažetcima članaka na Hrčku, prema kojima je definiran njihov odaziv na katalogu, ovdje ne možemo tvrditi da su korištene u istom značenju kao i u slučaju tematskih dodatnih oznaka, podatke u tablicama br. 1 do br. 4 za odaziv u mrežnim izvorima treba promatrati s tom ogradom.

Skupine su tematskih dodatnih oznaka prema vrstama riječi sljedeće:

- imenice (jednorječne riječi), kojima se označuju osobine ili svojstva nekoga predmeta (npr. autentičnost, brojivost, ljekovitost, produktivnost, sročnost, stabilnost, učinkovitost, ugroženost, itd.)

Tablica 1. Primjeri složenih predmetnih odrednica

\begin{tabular}{|l|l|l|}
\hline Primjeri složenih predmetnih odrednica & Katalog & Mrežni izvori \\
\hline $\begin{array}{l}\text { Račić, Josip, 1885-1908 (Portret žene s kravatom) - } \\
\text { autentičnost }\end{array}$ & 10 & 36 \\
\hline hrvatski jezik - imenice - brojivost & 5 & 5 \\
\hline laneno ulje - ljekovitost & 82 & 2 \\
\hline
\end{tabular}

29 Mrežni katalog KGZ-a [citirano: 2021-03-17]. Dostupno na: https://katalog.kgz.hr/pages/search.aspx? \& currentPage $=1$ \& searchById $=-1 \&$ age $=0$.

30 Hrčak: portal hrvatskih znanstvenih i stručnih časopisa [citirano: 2021-03-17]. Dostupno na: https://hrcak.srce.hr. 


\begin{tabular}{|l|l|l|}
\hline Primjeri složenih predmetnih odrednica & Katalog & Mrežni izvori \\
\hline $\begin{array}{l}\text { znanstvenici - produktivnost - istraživanje - } \\
\text { Hrvatska - 1985/1989. }\end{array}$ & 56 & 89 \\
\hline valuta - stabilnost & 11 & 235 \\
\hline antibiotici - učinkovitost & 36 & 285 \\
\hline vukovi - ugroženost - Hrvatska & 20 & 15 \\
\hline
\end{tabular}

Neke od tematskih dodatnih oznaka u toj skupini, kao i u skupinama koje slijede, koriste se isključivo uz određenu vrstu vodećih odrednica, dok druge značenjski dopunjavaju različite predmete. Tako je na primjer odrednica brojivost vezana isključivo uz određeni jezik (hrvatski jezik - imenice - brojivost), dok se odrednica učinkovitost dodaje predmetima iz područja ekonomije, prava, obrazovanja, medicine itd. Na primjer:

odgojno-obrazovni sustav - učinkovitost - Finska

javna uprava - učinkovitost - Hrvatska - 2005.

oglašavanje - učinkovitost - mjerenje

zakonodavstvo - učinkovitost - Hrvatska

U glavnom rječniku usvojene su vodeće odrednice koje također označuju različita svojstva (npr. agresivnost) i koriste se i kao dodatne odrednice (npr. djeca - agresivnost). Stoga se u pomoćni rječnik odabiru samo one tematske dodatne oznake koje su nužne i dostatne za dodatno označivanje osobina ili svojstva pojedinih predmeta (npr. sročnost kao svojstvo određenoga jezika).

- glagolske imenice (jednorječne riječi), kojima se označuje radnja, djelovanje ili proces (npr. arhiviranje, bombardiranje, dijagnosticiranje, financiranje, formiranje, imenovanje, istraživanje, korištenje, mjerenje, normiranje, očuvanje, poticanje, spašavanje, suzbijanje, štovanje, usvajanje, uređivanje, vještačenje)

Tablica 2. Primjeri složenih predmetnih odrednica

\begin{tabular}{|l|l|l|}
\hline Primjeri složenih predmetnih odrednica & Katalog & Mrežni izvori \\
\hline World Wide Web - arhiviranje & 11 & 6 \\
\hline Zadar - bombardiranje - 1943/1944. & 18 & 5 \\
\hline predsjednički izbori - financiranje - Hrvatska - 2005. & 123 & 128 \\
\hline mladi - religioznost - istraživanje - Jugoslavija - 1975. & 1918 & 630 \\
\hline
\end{tabular}




\begin{tabular}{|l|l|l|}
\hline Primjeri složenih predmetnih odrednica & Katalog & Mrežni izvori \\
\hline Majka Bogorodica - štovanje - Hrvatska - zbornici & 69 & 19 \\
\hline Židovi - spašavanje - Rijeka - 1938/1944. & 22 & 38 \\
\hline strani jezici - usvajanje - psihološko gledište & 30 & 52 \\
\hline
\end{tabular}

Za označivanje specifične podteme nekoga predmeta potrebno je u nekim slučajevima koristiti tematsku dodatnu odrednicu koja je bliskoznačna postojećim vodećim ili tematskim dodatnim odrednicama. Radi se o slučajevima kada vodeća odrednica značenjski ne odgovara sadržajima u građi. Primjer je uvođenje tematske dodatne oznake financiranje. Ona je uvedena u rječnik uz postojeće vodeće odrednice ,financije“ i ,javne financije“. Predmetna odrednica ,financije“ koristi se u najširem značenju i označuje sve poslove povezane s novčanim sredstvima, kao i ekonomsku znanost o novčanim sredstvima (obuhvaća teoriju i praksu vezanu uz prikupljanje, raspodjelu, preraspodjelu i trošenje novčanih sredstava), a javne financije njezin su uži pojam. Obje se odrednice koriste samo kao vodeće odrednice. $^{31}$

Tematska dodatna oznaka financiranje, stavljena iza naziva različitih vrsta ustanova, organizacija, djelatnosti ili proizvoda, omogućuje da se označe sadržaji koji govore o osiguravanju financijskih sredstava za njih. Predmetni niz uz koji se ta odrednica vezuje, prilično je velik, te je izdvojeno nekoliko predmetnih odrednica radi ilustracije. ${ }^{32}$

Primjeri korištenja tematske dodatne oznake financiranje:

$$
\begin{aligned}
& \text { cestogradnja - financiranje - Jugoslavija } \\
& \text { državna poduzeća - financiranje - Jugoslavija - 1918/1941. } \\
& \text { Gordogan (časopis) - financiranje } \\
& \text { Hrvatska. Oružane snage - financiranje } \\
& \text { investicijski projekti - financiranje - priručnici } \\
& \text { Katolička crkva - financiranje } \\
& \text { lokalna samouprava - financiranje - Slovenija } \\
& \text { znanstveno-istraživačka djelatnost - financiranje - Europa }
\end{aligned}
$$

\footnotetext{
31 Cjelovit popis složenih predmetnih odrednica s vodećom odrednicom „financije“ vidi na stranicama mrežnoga kataloga KGZ-a. [citirano: 2020-12-04]. Dostupno na: https://katalog. $\mathrm{kgz}$.hr/pagesResults/browseResults.aspx? \& currentPage $=1 \&$ searchById $=30 \&$ sort $=0 \&$ age $=0 \& \mathrm{~s}-$ pid $0=30 \& \operatorname{spv} 0=$ financije.

${ }^{32}$ Cjelovit popis složenih predmetnih odrednica s tematskom dodatnom oznakom nalazi se na stranicama mrežnoga kataloga KGZ-a. [citirano: 2020-12-04]. Dostupno na: https://katalog. $\mathrm{kgz}$.hr/pagesResults $/$ browseResults. aspx? \& currentPage $=1 \&$ searchById $=30 \&$ sort $=0 \&$ age $=0 \&$ s$\operatorname{pid} 0=30 \&$ spv $0=$ financiranje.
} 
Iz sličnih razloga uvedena je i tematska dodatna oznaka bombardiranje uz postojeću tematsku dodatnu odrednicu zračne operacije. Odrednicu zračne operaci$j e$ koristimo iza naziva ratova ili vojnih organizacija koje provode zračne operacije (npr. Drugi svjetski rat <1939/1945> - zračne operacije - Francuska). Odrednicu bombardiranje koristimo iza naziva mjesta koja su bila bombardirana (Kosovo bombardiranje - 1999.).

U predmetnom se jeziku KGZ-a, prilikom korištenja tematske dodatne oznake istraživanje, navodi i godina kada je istraživanje provedeno, uvijek kada se to iz dokumenta može točno utvrditi. Za građu koja se bavi istraživanjima pojava koje su značajno obilježene društvenim kontekstom, kao što je recimo religioznost, godine su važan podatak, a iz naslova ili godine objave dokumenta nije uvijek moguće saznati kada je istraživanje provedeno. Također, novoobjavljena građa može analizirati i neka prije provedena istraživanja, a ne samo ona nova. Stoga se uz predmete koji imaju tematsku dodatnu oznaku istraživanje, navode i godine. Na primjer:

$$
\begin{aligned}
& \text { nacionalni identitet - istraživanje - Hrvatska - 1985/1989. } \\
& \text { religioznost - istraživanje - Hrvatska - 1985/1989. } \\
& \text { religioznost - istraživanje - Hrvatska - 1996/2010. } \\
& \text { tolerancija - istraživanje - Hrvatska - 2009. } \\
& \text { političke vrijednosti - istraživanje - Hrvatska - 1985/1989. }
\end{aligned}
$$

Mrežni katalozi omogućuju sami po sebi bolje okupljanje građe nego što je to bio slučaj s katalozima na listićima, tako da pridodavanje godina u ovim slučajevima ne narušava okupljanje građe, a ujedno pridonosi informativnosti i boljemu odabiru s gledišta korisnika.

- imenice (jednorječne riječi), kojima se označuju različiti aspekti predmeta korištenjem pojmova širokoga opsega, bez specifičnoga sadržaja (npr. metode, svojstva, teorije, vrste) i/ili pojmova specifičnijega sadržaja (npr. abdikacija, anomalije, hospitalizacija, kodifikacija, konstrukcija, konzumacija, njega, praizvedba, pogreške, predstavnici, rehabilitacija, rekordi, skrb, transliteracija, ugradnja, zastara).

Tablica 3. Primjeri složenih predmetnih odrednica

\begin{tabular}{|l|l|l|}
\hline Primjeri složenih predmetnih odrednica & Katalog & Mrežni izvori \\
\hline tradicijske dječje igračke - $\mathbf{i z r a d a}$ - Hrvatska & 185 & 66 \\
\hline stadioni - konstrukcija & 11 & 197 \\
\hline dojenčad - $\boldsymbol{n j e g a}$ - priručnici za djecu & 117 & 133 \\
\hline
\end{tabular}




\begin{tabular}{|l|c|c|}
\hline Primjeri složenih predmetnih odrednica & Katalog & Mrežni izvori \\
\hline $\begin{array}{l}\text { Vojnović, Ivo, književnik, 1857-1929 (Ekvinocijo) - } \\
\text { praizvedba - 1903. }\end{array}$ & 5 & 1 \\
\hline hrvatsko naivno slikarstvo - predstavnici & 46 & 13 \\
\hline kinesko pismo - transliteracija & 4 & 6 \\
\hline kazneno djelo - zastara & 4 & 39 \\
\hline
\end{tabular}

- imenske sintagme (dvije ili više riječi koje čine sintaktičku i semantičku cjelinu) i drugi višerječni izrazi koji su nastali povezivanjem dviju riječi veznikom ,ii“, kojima se označuju različiti složeni aspekti predmeta. ${ }^{33}$

Tu skupinu čine različite vrste djelovanja, položaja, posljedica, savjeta, tumačenja, utjecaja, uloga, gledišta (npr. kulturno djelovanje, prevoditeljsko djelovanje, geografsko-prometni položaj, jezični savjeti, zdravstveni savjeti, povijesne veze, njemački utjecaji, antički utjecaji, prikazi u stranom tisku, prikazi na novinskim web portalima). Tu se ubrajaju i višerječni izrazi kao što su, naprimjer: vrste i nazivi, održavanje i popravci, likovne teme i motivi, kulturne i znanstvene veze, dijagnostika i liječenje).

Tablica 4. Primjeri složenih predmetnih odrednica

\begin{tabular}{|l|c|c|}
\hline Primjeri složenih predmetnih odrednica & Katalog & Mrežni izvori \\
\hline $\begin{array}{l}\text { intelektualci - društvena uloga - Europa, istočna - 20. } \\
\text { st. - eseji }\end{array}$ & 382 & 10 \\
\hline Isus Krist - filmske teme i motivi & 65 & 0 \\
\hline COVID-19 <zarazna bolest> - gospodarske posljedice & 9 & 1 \\
\hline Franjevci - književno djelovanje - Šibenik - 17/18. st. & 47 & 1 \\
\hline kazalište - Zagreb - 1840/1860. - njemački utjecaji & 7 & 0 \\
\hline $\begin{array}{l}\text { Salinger, Jerome David, 1919-2010-odnos prema } \\
\text { ženama }\end{array}$ & 19 & 0 \\
\hline $\begin{array}{l}\text { Šenoa, August, 1838-1881 (djela) - utjecaj usmene } \\
\text { književnosti }\end{array}$ & 20 & 0 \\
\hline puževi - vrste i nazivi - Jadran & 48 & 0 \\
\hline
\end{tabular}

33 I ovdje se, kao i u tehničkom rječniku, u slučaju imenskih sintagmi najčešće koriste imenice s atributom (npr. leksikografsko djelovanje, pastoralni posjeti, glasoviti govori), zatim imenice povezane s drugom imenicom pomoću prijedloga (odjeci u svijetu, odnos prema ženama) te imenice $\mathrm{s}$ imenicom u genitivu (gosti emisije, stavovi stručnjaka). 
Korištenje sintagmi omogućuje da se vrlo precizno iskaže neki aspekt predmeta o kojemu je riječ. Uz njih se mogu, kao i u slučaju svih ostalih predmetnih odrednica, postaviti dva pitanja: pitanje ekonomičnosti ${ }^{34}$ i pitanje koje su predmetne odrednice dostatne i nužne da bi bile usvojene u rječnik. S obzirom na to da odluke mogu ići i u smjeru proširivanja i u smjeru smanjivanja broja elemenata u bibliografskom opisu, ${ }^{35}$ na svakome je predmetnom sustavu da odredi kako će definirati veličinu rječnika i kontrolirati njegov rast.

U nastojanju da se precizno iskaže predmet, učinkovitima su se pokazale sintagme kojima se označuju različite vrste djelovanja pojedinaca ili skupina osoba i koje istovremeno dobro okupljaju građu (npr. književno djelovanje, prevoditeljsko djelovanje, znanstveno djelovanje, itd.).

Primjeri složenih odrednica:

Isusovci - književno djelovanje - Hrvatska - 17/18 st.

Isusovci - prosvjetno djelovanje - Bosna i Hercegovina

Isusovci - znanstveno djelovanje - povijest

Kukuljević Sakcinski, Ivan, 1816-1899-jezikoslovno djelovanje

Kukuljević Sakcinski, Ivan, 1816-1899-političko djelovanje

liječnici - književno djelovanje - Hrvatska

Kao posebnu podskupinu u toj skupini, zbog brojnosti, možemo izdvojiti tematske dodatne oznake za gledišta. One okupljaju brojna znanstvena, teorijska, interdisciplinarna, ideološka, religijska gledišta (npr. filozofsko, psihološko, islamsko, kulturološko, psihofiziološko, ustavnopravno, marksističko, neoliberalno, humorističko).

Primjeri složenih odrednica:

Dostojevskij, Fedor Mihajlovič, 1821-1881 (djela) - filozofsko gledište

bolovi u leđima - psihološko gledište

država - islamsko gledište

smrt - budističko gledište

agrarno pitanje - marksističko gledište

javno zdravstvo - neoliberalno gledište

majčinstvo - feminističko gledište

Nijemci - način života - humoristično gledište

34 Načelo ekonomičnosti kaže da se tamo gdje postoji više načina za postizanje željenoga cilja, treba odlučiti za najekonomičniji način i nastojati ograničiti metapodatke dopustive u bibliografskom opisu. Usp. Svenonius, E. Nav. dj., str. 70.

35 Usp. isto, str. 79-80. 
Kao posljedica okolnosti da se nazivlje predmetnoga jezika KGZ-a razvijalo najviše u području društvenih i humanističkih znanosti, gdje se značenja mnogih pojmova ne mogu jednoznačno odrediti ili su nestabilna, a interdisciplinarnost je čest istraživački pristup, u rječnik predmetnoga jezik uveden je velik broj gledišta. Trenutno ih je u rječniku više od sto pedeset. Velik broj gledišta povezan je s problemom normativnoga nadzora usvojenih predmetnih odrednica i kontrolom rasta pomoćnoga rječnika.

\subsection{Normiranje tematskih dodatnih oznaka}

Uvođenje tematskih dodatnih oznaka u predmetni jezik KGZ-a bilo je obilježeno nedovoljnom normativnom kontrolom. U formatu UNIMARC za pregledne zapise $^{36}$ pri normiranju tih odrednica koristila su se samo dva polja - polje 250 , u koje se odrednica upisivala kao opći pojam, te polje 820, u koje se upisivao naziv te vrste odrednica. Takva je praksa dovela do nekontroliranoga rasta pomoćnoga rječnika i stvaranja zalihosti. Zbog toga je krajem 2019. godine odlučeno da se započne s revizijom tematskih dodatnih oznaka. Prilikom revizije sve se odrednice normiraju tako da im se određuju uvjeti korištenja, to jest definiraju značenja i propisuje sintaksa u skladu sa Smjernicama za izradbu predmetnih preglednih kataložnih jedinica i uputnica. ${ }^{37}$

Odabrane odrednice upisuju se kao oznake za opći pojam u polje 250. Uvjeti korištenja određuju se dalje kroz polja 305 i 330 - polja za napomene, zatim kroz polje 450 - uputnice za neusvojene pojmove i polje 550 - uputnice za srodne / šire ili uže usvojene pojmove (ako ih ima). Moguće je navesti i polje izvora 810 iako nije obvezno. U polje 820 za upotrebu pojma upisuje se naziv te vrste predmetnih odrednica - tematska dodatna oznaka.

Prema dogovorenoj praksi normiranja tematskih dodatnih oznaka u predmetnom sustavu KGZ-a korištenje polja formata UNIMARC ovisi o opsegu usvojenih pojmova. Tako za pojmove kojima je opseg širok, poput pojmova „svojstva“, „teorije“ ili „vrste“, ne treba koristiti polje 810. Polja 305, 330 i 820 obvezna su za sve tematske dodatne oznake.

\footnotetext{
36 Priručnik za UNIMARC: Format za pregledne zapise. / s engleskoga prevela S. Radovčić; hrvatske primjere odabrali i izradili Z. Ivanović, R. Krauth, M. Miletić Drder, S. Radovčić. 1. hrvatsko izd. (prema 2. prerađenom i proširenom izd. izvornika). Zagreb: Hrvatsko knjižničarsko društvo, 2004.

37 Smjernice za izradbu predmetnih preglednih kataložnih jedinica i uputnica. / [preporučila] Radna Skupina za izradbu Smjernica za datoteke predmetnih preglednih kataložnih jedinica Sekcije za klasifikaciju i indeksiranje Odjela za bibliografski nadzor Međunarodnog saveza knjižničarskih društava i ustanova; s engleskog prevela, hrvatske primjere odabrala i izradila J. Leščić. Zagreb: Hrvatsko knjižničarsko društvo, 1999.
} 
Primjer iz normativne baze:

\begin{tabular}{|c|c|c|}
\hline $250 \mathrm{a}$ & Opći pojam & abdikacija \\
\hline $305 \mathrm{a}$ & Objašnjenje & $\begin{array}{l}\text { Vidi kao tematsku dodatnu oznaku iza ime- } \\
\text { na vladara i imena papa, kao i iza pojma koji } \\
\text { označuje skupinu osoba na koju se odnosi. } \\
\text { Npr.: }\end{array}$ \\
\hline $305 \mathrm{~b}$ & Odrednica na & $\begin{array}{l}\text { Obrenović, Milan, srpski kralj, 1854-1901- } \\
\text { abdikacija koju se upućuje }\end{array}$ \\
\hline $305 \mathrm{~b}$ & $\begin{array}{l}\text { Odrednica na } \\
\text { koju se upućuje }\end{array}$ & pape - abdikacija \\
\hline $330 \mathrm{a}$ & Opća napomena & $\begin{array}{l}\text { Ovu odrednicu koristimo za građu koja govori } \\
\text { samo o odreknućima/ostavkama od vladarskih } \\
\text { prijestolja (kraljevi, carevi) ili papinske vlasti, } \\
\text { za razliku od ostavki političkih dužnosnika ili } \\
\text { rukovoditelja. }\end{array}$ \\
\hline 450 & $\begin{array}{l}\text { Identifikator pre- } \\
\text { glednoga zapisa }\end{array}$ & odreknuće \\
\hline 810 & Navod & $\begin{array}{l}\text { Veliko odreknuće / Roberto Rusconi. } \\
\text { Zagreb, } 2014 .\end{array}$ \\
\hline 810 & Navod & $\begin{array}{l}\text { https://enciklopedija.hr/Natuknica. } \\
\text { aspx?ID=73 (2020-05-18) }\end{array}$ \\
\hline 820 & $\begin{array}{l}\text { Tekst } \\
\text { napomene }\end{array}$ & Tematska dodatna oznaka \\
\hline
\end{tabular}

S gledišta sintakse, tematska dodatna oznaka u pravilu slijedi odmah iza vodeće oznake kojoj značenje proširuje i uz koju je kontekstualno vezana. Te se odrednice mogu dodati i na kraju složenih predmetnih odrednica (npr. znanost - renesansa arapski utjecaji). Također je moguće koristiti istovremeno dvije tematske dodatne oznake (npr. bolesna djeca - hospitalizacija - psihološko gledište).

Prilikom revizije, osim normiranja odrednica, iz rječnika se brišu one odrednice koje su se pokazale suvišnima. Zalihost se u rječniku stvarala na nekoliko načina. Prvi je bio posljedica istovremenoga korištenja bliskoznačnih riječi bez određivanja relacijskih semantičkih odnosa i područja upotrebe za svaku pojedinu odrednicu. Primjer su takvih odrednica:

- sprječavanje, suzbijanje, prevencija, ili

- stilska obilježja, stilistička analiza, stil, ili

- geopolitička obilježja, geopolitički položaj. 
Neke su se odrednice/riječi pokazale suvišnima zbog nedovoljne informativnosti. Njihovim se korištenjem nije dobivalo na željenoj preciznosti u dodatnom označivanju predmeta. Primjerice:

Hrvatska - vanjska politika - 2000. - ciljevi

zadovoljstvo studijem - faktori - istraživanje - Hrvatska - 2015/2016.

diplomacija - funkcije

bećarac - obilježja

Zalihosti je u nekim slučajevima pridonijelo i korištenje tematskih dodatnih oznaka za gledišta uz vodeće odrednice kojima je značenje istovjetno značenju koje se pridodaje gledištem. Na primjer:

emocije - psihološko gledište

anketa - metodološko gledište

Činjenica da se rječnička domena počela definirati krajem 1990.-ih i početkom 2000.-ih godina kada korištenje interneta, a osobito pametnih telefona još nije bilo sveprisutno, posebno među mladima, ostavila je traga na predmetno označivanje. Vrijeme je to kada se u srednjim školama, sve do uvođenja državne mature 2008. godine, još intenzivno posuđuje lektira i sastavljaju pisani radovi na različite teme. Jedan broj tematskih dodatnih oznaka nastao je upravo kako bi se za potrebe mlađih korisnika označila građa koja na sažet način prenosi potrebnu informaciju, a među njima su odrednice određenje pojma i osnovni podaci:

bioetika - određenje pojma

feudalizam - određenje pojma

usmena književnost - određenje pojma

Hrvatska - osnovni podaci - priručnici za djecu

morske kornjače - osnovni podaci - tematske slikovnice

virusi-osnovni podaci

Ti primjeri pokazuju kako je pitanje korištenja i relevantnosti usvojenih predmetnih odrednica, između ostaloga, podložno i ,,uporabnom ili situacijskom kriteriju usklađivanja ${ }^{\text {“38 }}$ između promjenljivih potreba korisnika i predmetnoga jezika. Gledajući danas iz perspektive prisutnosti digitalnih tehnologija i mrežno dostupnih sadržaja, kao i promijenjenih obrazovnih zahtjeva, jasno je da se mijenjaju i potrebe predmetnoga označivanja određene građe.

38 Taj kriterij navodi autor T. Saračević analizirajući korisničke kriterije za relevantnost informacija. Usp. Saračević, T. Relevantnost i kako se istraživala. // Vjesnik bibilotekara Hrvatske 50, 1/2(2007), str. 1-26. [citirano: 2020-12-14]. Dostupno na: http://www.hkdrustvo.hr/vbh-arhiva/ broj/95. 


\section{Kvaliteta i učinkovitost usvojenih predmetnih odrednica}

S gledišta korisnika predmetni jezik treba omogućiti pronalaženje i okupljanje dokumenata koji imaju isti informacijski sadržaj. Da bi se to postiglo, potrebno je predmetnim označivanjem osigurati pronalaženje svih relevantnih dokumenata. Provjera uspješnosti toga postupka provodi se standardnim mjerama učinkovitosti za sve informacijske sustave (uz neke varijacije), a to su mjere odaziva i točnosti. Te mjere iskazuju vjerojatnost (postotak) suglasnosti između onoga što je sustav ponudio ili definirao kao relevantno (relevantnost sustava) i onoga što je korisnik procijenio ili pronašao kao relevantno (korisnička relevantnost). ${ }^{39}$ Odnosno, da bi se ispitala učinkovitost usvojenih predmetnih odrednica za pretraživanje građe (s gledišta sustava), potrebno je provesti mjerenja odaziva i točnosti prema odabranom kriteriju relevantnosti. Učinkovitost predmetnoga označivanja moguće je mjeriti i nekom varijantom tih osnovnih mjera, kao što je recimo dosljednost $u$ označivanju. Dosljednost u označivanju odnosi se na stupanj slaganja u odabiru predmetnih odrednica za označivanje istoga dokumenta dvaju različitih predmetnih stručnjaka ili na stupanj slaganja pri označivanju istoga dokumenta od strane jednoga (istog) predmetnog stručnjaka, ali s određenim vremenskim odmakom. ${ }^{40}$

Korisnički kriteriji relevantnosti, kojima se vode različiti korisnici pri pretraživanju informacija, poznati su nam na temelju brojnih stranih istraživanja. Pregledno su prikazani u radu informacijskog stručnjaka Tefka Saračevića, koji ih sažima u sedam glavnih grupa. ${ }^{41}$ Kao relevantne kriterije za korisnika na razini sadržaja autor navodi: temu, kvalitetu, dubinu, domet, starost informacije, obradu i jasnoću. Na razini spoznajnoga usklađivanja važan je kriterij razumljivost, a za njegovo postizanje bitna je i dobra jezična usklađenost između prirodnoga jezika korisnika i predmetnoga jezika knjižničara.

U tome bi smislu kvalitetu ponuđenih rješenja u pomoćnom rječniku tematskih dodatnih oznaka (kao i u glavnome) trebalo provjeriti istraživanjima. U domaćoj knjižničnoj literaturi pronalazimo vrijedne radove o predmetnom označivanju, o načinima na koje se uspostavlja normativni nadzor u sadržajnoj obradi u različitim predmetnim sustavima u svijetu, kao i o različitim mogućnostima predmetnih pretraživanja. Istraživanja koja se bave mjerenjem učinkovitosti predmetnih odrednica prema odabranome istraživačkom pristupu i dalje su rijetka. ${ }^{42}$

\footnotetext{
39 Usp. isto, str. 4.

40 Petr Balog, K.; I. Majlinger Tanocki. Dosljednost predmetnog označivanja elektroničke građe u mrežnim katalozima hrvatskih narodnih knjižnica. // Vjesnik bibliotekara Hrvatske 57, 1/3(2014), str. 71. [citirano: 2021-03-19]. Dostupno i na: http://www.hkdrustvo.hr/vjesnik-bibliotekara-hrvatske/index.php/vbh/article/view/113.

41 Navedeno prema Petr Balog; I. Majlinger Tanocki. Nav. dj., str. 16.

42 Istraživački rad te vrste za sada je samo jedan. Usp. isto.
} 


\section{Zaključak}

Svaki predmetni jezik ovisan je u određenoj mjeri o svome pomoćnom, ne-tehničkom rječniku. Odabir dodatnih predmetnih odrednica koje čine taj rječnik povećava informativnu vrijednost glavnoga rječnika i kvalitetu predmetnoga jezika u cjelini.

Odabirom i korištenjem tematskih dodatnih oznaka u predmetnom jeziku KGZ-a nastojalo se postići što veću točnost $i$ iscrpnost u označivanju specifičnih aspekata različitih predmeta prisutnih većinom u građi s društvenih i humanističkih područja, imajući pri tome u vidu potrebe korisnika. Istovremeno, kroz praksu predmetnoga označivanja pokazalo se da izostanak potrebnoga normativnog nadzora nad tim odrednicama uzrokuje stvaranje zalihosti, neinformativnih odrednica i/ili njihovo pogrešno korištenje. Stoga se prilikom revizije pomoćnoga rječnika provodi normiranje svih tematskih dodatnih oznaka, kao i ispravci potrebni zbog pogrešnog načina na koji su neke od tih odrednica korištene u složenim predmetnim odrednicama.

Međutim, i kada je normativni nadzor nad predmetnim sustavom dosljedno proveden, odluke koje su vezane uz odabir elemenata koji će se uvesti u bibliografski opis, odnosno predmetnih odrednica u rječnik, nisu uvijek jednostavne. Ako se dodatnim odrednicama ne označi dovoljno precizno pojedine aspekte vodećih odrednica ili podteme širih tema, nazivi u rječniku bit će preopćeniti, a sam rječnik nedovoljno informativan. Ako se predmeti previše detaljno opišu, riskira se usvajanje suvišnih elemenata u rječniku i stvaranje zalihosti.

Propust može biti napravljen i pri jezičnim odabirima, odnosno odabranim označiteljima različitih sadržaja, pa predmetne odrednice u nekim slučajevima korisnicima mogu biti nedovoljno razumljive. Odluka o tome od koliko će se elemenata ili riječi (i u kojem redoslijedu) izgraditi naziv, oblikovati podtema ili aspekt predmeta, ovisi i o izboru riječi od kojih će se oblikovati odrednica.

Nastojanje da se kroz predmetnu obradu građe stvore što kvalitetniji metapodatci i omogući korisnicima pronalaženje relevantnih dokumenata, nudi brojne izazove. Kvalitetu i učinkovitost ponuđenih rješenja u predmetnom jeziku, kao i općenito ponašanje korisnika pri predmetnom pretraživanju, trebalo bi provjeravati kontinuiranim istraživanjima. 


\section{LITERATURA}

Birtić, M.; G. Blagus Bartolec; J. Budja; L. Hudaček; Ž. Jozić; B. Kovačević; K. Lewis i suradnici. Hrvatski pravopis. Zagreb: Institut za hrvatski jezik i jezikoslovlje, 2013. [citirano: 2020-10-14]. Dostupno i na: https://pravopis.hr.

Cordeiro, M. I. Organizacija znanja i predmetne odrednice: Jačanje jedne od najslabijih točaka međunarodnog knjižničarstva. // Vjesnik bibliotekara Hrvatske 44, 1/4(2001), 129-144.

Hudaček, L.; M. Mihaljević. Hrvatski terminološki priručnik. 3. ispravljeno izd. Zagreb: Institut za hrvatski jezik i jezikoslovlje, 2012.

Juraga, M. Specifičnost u oblikovanju predmetnih odrednica za izražavanje odnosa ili utjecaja u sustavu predmetne obrade Knjižnica grada Zagreba. // Vjesnik bibliotekara Hrvatske 57, 1/3(2014), 105-116. [citirano 2020-11-05]. Dostupno i na: http:// www.hkdrustvo.hr/vjesnik-bibliotekara-hrvatske/index.php/vbh/article/view/114.

Petr Balog, K.; I. Majlinger Tanocki. Dosljednost predmetnog označivanja elektroničke građe u mrežnim katalozima hrvatskih narodnih knjižnica. // Vjesnik bibliotekara Hrvatske 57, 1/3(2014), 69-103. [citirano: 2021-03-19]. Dostupno i na: http:// www.hkdrustvo.hr/vjesnik-bibliotekara-hrvatske/index.php/vbh/article/view/113.

Pravilnik i priručnik za predmetne odrednice. Zagreb: Nacionalna i sveučilišna knjižnica, 2019. [citirano: 2020-10-27]. Dostupno na: http://ps.nsk.hr/wp-content/ uploads/2019/09/Pravilnik-i-priru\%C4\%8Dnik-za-predmetne-odrednice-srpanj-2019-v2.pdf.

Principles unederlaying subject heading languages (SHLs). / edited by I. Lopes and J. Beall; Working Group on Principles Underlying Subject Heading Languages; Approved by the Standing Committee of the IFLA Section on Classification and Indexing. München: K. G. Saur, 1999.

Priručnik za UNIMARC: Format za pregledne zapise. / s engleskoga prevela S. Radovčić; hrvatske primjere odabrali i izradili Z. Ivanović, R. Krauth, M. Miletić Drder, S. Radovčić. 1. hrvatsko izd. (prema 2. prerađenom i proširenom izd. izvornika). Zagreb: Hrvatsko knjižničarsko društvo, 2004.

Svenonius, E. Intelektualne osnove organizacije informacija. Lokve: Benja, 2005.

Saračević, T. Relevantnost i kako se istraživala. // Vjesnik bibilotekara Hrvatske 50, 1/2(2007), 1-26. [citirano: 2020-12-14]. Dostupno i na: http://www.hkdrustvo.hr/ vbh-arhiva/broj/95.

Smjernice za izradbu predmetnih preglednih kataložnih jedinica i uputnica. / preporučila Radna Skupina za izradbu Smjernica za datoteke predmetnih preglednih kataložnih jedinica Sekcije za klasifikaciju i indeksiranje Odjela za bibliografski nadzor Međunarodnog saveza knjižničarskih društava i ustanova; s engleskog prevela, hrvatske primjere odabrala i izradila J. Leščić. Zagreb: Hrvatsko knjižničarsko društvo, 1999. 
Štrbac, D.; M. Vujić. Pravilnik za predmetni katalog. Zagreb: Knjižnice grada Zagreba, 2004.

Uvjeti za funkcionalnost predmetnih autoriziranih podataka: Konceptualni model. / urednice M. Lei Zeng, M. Žumer i A. Salaba; IFLA-ina Radna skupina za Uvjete za funkcionalnost predmetnih preglednih zapisa (FRSAR); Odobrio Stalni odbor IFLA-ine Sekcije za klasifikaciju i indeksiranje u lipnju 2010.; s engleskog preveo P. Perožić. Zagreb: Hrvatsko knjižničarsko društvo, 2012.

Urbanija, J. Metodologija izrade tezaurusa. Zagreb: Naklada Nediljko Dominović, 2005. 